Article

\title{
The Symbiotic Bond of Income Equality and Organizational Equilibrium
}

\author{
Vicente Roca-Puig ${ }^{(D)}$ \\ Department of Business Administration and Marketing, Faculty of Law and Economic Sciences, \\ Universitat Jaume I, 12071 Castellón, Spain; roca@emp.uji.es
}

Received: 14 September 2020; Accepted: 5 November 2020; Published: 8 November 2020

\begin{abstract}
The corporate sustainability literature postulates that companies are social entities that constantly interact with the society in which they are located. Although this idea is generally accepted, one persistent research gap in this field relates to testing this connection through quantitative empirical studies. In this study, we shed light on the bidirectional relationship between income inequality and organizational equilibrium (i.e., balance in the employment relationship). From data on 2525 companies covering a nine-year period and using longitudinal structural equation modeling, findings demonstrate that equity in the distribution of resources among people in a society positively influences equity in the distribution of resources between employer and employees, and vice versa. A symbiotic union of mutual benefit between society and business is, therefore, developed over time. Theoretical and practical implications of our findings are presented.
\end{abstract}

Keywords: income inequality; employment relationship; equity; social sustainability; longitudinal analysis; business and society; sustainable development goals

\section{Introduction}

A decade ago, Wilkinson and Pickett [1] published their famous best seller "The spirit level: Why more equal societies almost always do better", whose main thesis is that reducing income inequality is a way to increase the general welfare of a society. Income inequality refers to the imbalance in income distribution among people in a society, be it a region or a country, which allows a group certain opportunities for human development while denying them to another [2,3]. Income equality is the opposite of income inequality. Income equality is circumscribed within the social dimension of environmental sustainability, emphasizing its ethical principle of social equity and good quality of life [4-6]. Greater social equity is not only a moral issue but also has a political connotation in which achieving a less unequal society is prioritized as a target [5,7]. International organizations, such as the United Nations Organization (UN) in its 2030 Agenda for Sustainable Development, have embraced this objective. However, income inequality in most developed societies has increased significantly in the last decade [8]; therefore, it is especially important to recognize its antecedents [9].

Wilkinson and Pickett [1] identify companies as an essential social agent causing income inequality. Business decisions or strategies on how organizations distribute resources among their members can affect income inequality. Some organizational characteristics have already been identified as antecedents of income inequality, such as the disparity in remuneration between senior management and employees [9] or among employees with different employment characteristics [10], the implementation of a human resource management strategy [3,11], and employment concentration [8]. Despite all these efforts, we still lack a robust explanation of how companies influence income inequality, and more studies are needed to develop this approach [8,9,12-15].

In response to this call, we introduce a new business attribute as a precursor of income inequality that has not yet been examined in depth: organizational equilibrium. The corporate sustainability 
approach (e.g., [16-18]) embraces the seminal inducement-contribution model [19], in which the organizational equilibrium concept expresses an employment relationship focused on equity, obtained from the balance between the interests of two basic internal stakeholders: the employer and the employees [20]. More specifically, Roca-Puig [21] defines organizational equilibrium as the coalignment between human resource (HR) investment (i.e., inducement) and the return of this investment through labor productivity (i.e., contribution) in a company. Stakeholder theory [22] recognizes that for an organization to be sustainable there must be a significant coalignment in meeting the expectations of both stakeholders [23,24], emphasizing relationships that are mutually beneficial for employers and employees [25]. Organizational equilibrium is consistent with a "win-win" perspective in that the balance between the interests of employers (i.e., labor productivity) and employees (i.e., HR investment) is clearly mandatory for a sustainable organization.

This principle of sustainability can be extended to external stakeholders, such as the society or local community in which the organization develops its economic activity $[17,25,26]$. According to Plaza-Úbeda et al. [24], employers who adhere to the win-win model also tend to integrate other stakeholders' needs into their business strategies. Through stakeholder management, the ethical value of equity extends to society through the company's social collaboration network [4,6,27-29]; therefore, organizational equilibrium plays a fundamental role in achieving greater income equality. On the other hand, the reverse effect can also occur, that is, income inequality causes organizational equilibrium. Organizations adopt inequality-supporting values and norms that are prevalent in the broader society and internalize them within organizations, thus changing the nature of the employment relationship [12,30,31]. In the field of sustainability research, this organizational reproduction of income inequality is usually supported by institutional theory [32], which claims that a society's sociocultural values influence the way organizations behave in a given domain. (e.g., $[4,16,30,33]$ ).

Therefore, a two-way causal relationship between society and business is established that has been widely defended in the corporate sustainability literature, both theoretically and through qualitative analysis (e.g., [18,27-29,34-36]). In particular, Porter and Kramer ([27]; p. 89) postulate that organizations and society influence and support each other by forming a "symbiotic relationship" of mutual benefit. Authors, such as Amis et al. [30] and Bapuji et al. [12], also emphasize the bidirectional relationship between organizational actions and income inequality. In this way, we can view organizations as social actors for the creation of income inequality and, simultaneously, as locations where societal practices and values promoting inequality are institutionalized.

Paradoxically, very few studies corroborate this hypothesis through quantitative analysis, which would mean a significant advance in the sustainability field. As Dyllick and Hockerts [35] and Cosenz et al. [34] highlight, more quantitative testing of the hypothesis would be helpful to building a systematic theory of corporate sustainability. Furthermore, the society-business link needs to be tested through a dynamic approach $[15,27,34,37]$. The complexity of longitudinal studies means they are scarce and especially valuable in the field of human resources management [38], particularly when they are designed to examine their interrelationship with the objectives of the 2030 Agenda for the Sustainable Development [14]. In order to provide new empirical evidence, we designed an original longitudinal Structural Equation Model (SEM) that captures the bidirectional relationship between organizational equilibrium and income inequality over time. A longitudinal SEM improves our ability to understand a dynamic process, because its goal is "to find a reduced set of structural paths that can explain the pattern of associations in the data over time" ([39]; p. 183). In this case, we propose that an increase in organizational equilibrium will produce an increase in income equality and, in turn, an increase in income equality will increase organizational equilibrium. This bilateral association recurs cyclically, consolidating both societal social sustainability and organizational social sustainability. 


\section{Theoretical Framework}

\subsection{Organizational Equilibrium as a Core Principle of Organizational Social Sustainability}

The corporate sustainability literature holds that the ability of an organization to continue operating for a long period of time depends on its meeting the legitimate expectations of different participants because their respective interests are intrinsically connected and share a common need for satisfaction and well-being $[16,18,37,40-42]$. Therefore, a core principle of corporate sustainability is to achieve a certain degree of equilibrium or balance between stakeholders' interests $[18,43]$. For this purpose, a relationship of reciprocity or social exchange is established between the organization and its different stakeholders, whereby each of these participants helps the organization to achieve its particular objectives and, in return, the organization compensates them by making it easy for them to achieve their goals. The social exchange relationship rests on the ethical value of equity, by which the resource sharing decisions are fair and balanced between the organization and each of these stakeholders [18,40-42].

When balancing interests, those who maintain a closer relationship with the organization, especially employees, will have preference [41,42]. Consequently, sustainable organizations must prioritize maintaining a balance in the employment relationship, that is, between the interests of the employer and those of the employees. The concept of organizational social sustainability is linked to reciprocity, fair distribution, and equity in the employment relationship [11,44,45]. In this regard, the corporate sustainability approach involves the classic organizational equilibrium model of March and Simon [19], subsequently developed by authors, such as Tsui et al. [20] and Subramony et al. [46]. As March and Simon [19] state, the most obvious participants in the organization are the employees, who receive salaries and other bonuses in return for the labor (production) they provide to the organization. This organizational equilibrium between inducement and contribution allows a company to be sustainable and survive over time [19,43]. According to Roca-Puig [21], an organization will be sustainable if it preserves a positive coalignment between its HR investment (i.e., inducement) and its labor productivity (i.e., contribution). Organizational equilibrium represents equity between the interests of employees and employers, defined by the fit between HR investment and labor productivity. The inducements (i.e., HR investment) the organization makes extend beyond wages to also include measures that enhance the welfare of employees, such as training and job security $[19,20,31]$. HR investment will be reimbursed by employees in the form of favorable attitudes and collaborative behavior towards the organization, thus improving their work efficiency and operational performance. Labor productivity is one of the main criteria to evaluate the contribution employees make to the organization $[19,20,46]$. The outcome of this reciprocity process is the alignment of the particular interests of the employer with those of the employees. In March and Simon's [19] classic inducement-contribution model, a substantial level of mutuality-or shared satisfaction--produces more stable social exchanges; coalignment in the employer-employee relationship is, therefore, essential for an organization to be sustainable [43].

\subsection{The Double Causality between Organizational Equilibrium and Income Inequality}

Parallel to what happens in the company with the notion of organizational equilibrium, the ethical value of equity also underlies society through the concept of income equality. The social equity value implies that all members of society have equal access to resources and opportunities in order to achieve sustainable development and a good quality of life [4]. A fair and balanced distribution of income among members of a society contributes to improving the quality of life and well-being of the population as a whole [5,47]. By contrast, income inequality indicates discriminatory distribution of income among people within a society, which allows one group certain opportunities for human development while denying them to another [2,3]. This unfair scenario leads to less social cohesion, lack of social trust, and non-collaborative behaviors, thus limiting a society's social development $[1,2]$. Societal social sustainability can be interpreted as the function of guaranteeing better living conditions 
for the entire population; social equity is, therefore, an essential aspect of societal social sustainability that can be reflected by the level of income equality [6,45].

Organizational social sustainability is linked to societal social sustainability in as far as companies act as social actors that influence the sustainable development of society, by generating environmental externalities that can be both physical (e.g., reduction of industrial waste) and social [4], among which the reduction of income inequality is of particular note $[14,16,37]$. The corporate sustainability literature, based on stakeholder theory, develops this argument and poses that distributing the value created by corporations equitably among internal stakeholders can be extended to other company actions that involve external stakeholders (i.e., clients, suppliers, government). Organizational equity policy is thereby transmitted through its social network of contacts and eventually affects society in general $[4,6,7,18,27-29,48]$. Social networks consist of social exchange relations between individuals, groups and organizations that encourage reciprocity and the ethical value of equity shared by all these agents. The members of this network benefit from a social space of collaboration and mutual benefits that sanctions the violation of the ethical principle of equity, thus limiting the emergence and/or tolerance of income inequality in the society in which they operate. The knowledge generated through employer-employee dialogue and the employers' belief in the win-win arrangement has the potential to generate and develop organizational capabilities in the management of collaborations with other societal agents, and create mutual advantages that improve the long-term economic health, stability and social cohesion of the local community [24].

Thus, for example, Hutchins and Sutherland [6] analyze the social exchange relationship between organization and supplier, and affirm that socially responsible practices begin in individual companies and then move forward through their supply chains until they reach the macro level of social sustainability. Porter and Kramer [27,28]) and Santos [29] propose the concept of organizational social responsibility clusters, consisting of structured networks of multiple participants coordinated around shared projects and oriented towards the implementation of business policies and strategies grounded in the basic principles of equity and cooperation that help to generate a territorial context of global sustainability. These agglomerations of companies, generally located within a common geographical area, initiate and maintain interactions with other entities and local actors to optimize joint social responsibility practices. Through participatory governance, these multiple participants are able to reach other social agents beyond companies and, therefore, can take on broader commitments that allow for significant improvements in the quality of life of the community in their surrounding field of influence [27]. In short, companies with a sustainable organizational structure through their social network can positively influence the society or territory in which they are located. Therefore, we can state that an increase in companies' organizational equilibrium will produce a decrease in income inequality in the region in which they are located.

Conversely, societal social sustainability can also influence organizational social sustainability. As Stubbs and Cocklin [18] indicate, a sustainable business model that balances the interests of different stakeholders is structured around the value of equity, which can only be presented when this moral principle is established in society. Lower territorial equity will limit companies' socially responsible initiatives [29]. The presence of income inequality in a territory is an indication of reduced social equity; this unethical value will, therefore, be transferred to companies, reducing the likelihood of establishing a balanced employment relationship between employer and employees. Therefore, an increase in income inequality in a society will lead to a reduction in organizational equilibrium of the companies located in that society. This argument from the corporate sustainability research is grounded in institutional theory, which holds that organizations adopt values and norms that are widespread in their society and internalize them within organizations to achieve acceptability and support for the firms' activity, known as legitimacy $[4,16,33]$. The cultural values of a society are permeable and imported by companies, thus conditioning the degree of balance in the employment relationship.

The cultural standards established in society act as obligations or guides (i.e., institutional pressures) for employers' strategic decisions $[4,16,37]$, so that the final decision on the level of 
organizational equilibrium, which normally falls on the employers, will inherently depend on those societal values and norms. When the ethical value of equity prevails in a society, then employers are forced to limit their own interest in order to respect and satisfy the interests of their employees. On the contrary, if the companies are located in a socioeconomic environment characterized by high income inequality, in which the ethical value of equity suffers, the compensation received is more likely to be reduced, thus putting the employer's interests before those of the employees. On the other hand, employees can also present opportunistic behaviors, passive attitudes and a lower reciprocity to the organization in an unequal society, which dissuades them from responding equitably to their employers' incentives [2]. The behavior of both stakeholders deriving from income inequality and poor living conditions weakens the employment relationship [2,12,31].

The above stakeholder and institutional theoretical approaches from the corporate sustainability research can be concurrent [16], which can establish a double causality [36] or symbiotic relationship $[27,28]$ of mutual support between society and business. This mutual dependence implies that social policies and business decisions must follow the principle of shared value, that is, choices must benefit both sides [27]. In the long term, the sustainable development of a society without the support of sustainable organizations is unlikely and, conversely, the subsistence of sustainable business models located in an environment characterized by reduced social sustainability is unlikely. Porter and Kramer [27] identify two points of intersection between companies and society, related to how organizations affect society and how society affects organizations.

Similarly, Bapuji et al. [12] raise these two questions, concretizing them in the study of income inequality and supporting a bidirectional relationship between income inequality and organizations. Among the mechanisms driving this bidirectional relationship identified by Bapuji et al. [12], we recognize the logics of stakeholders and institutions. Companies increase income inequality in a society by skewing value distribution in favor of shareholders (i.e., employers), and against non-shareholder stakeholders with a weaker position, such as employees, thus accentuating the imbalance in the employment relationship. Bidwell et al. [10] also support the idea that shareholders gain at the expense of employees and that this minor organizational equilibrium increases income inequality. Conversely, organizations show institutional employment practices by internalizing inequality-supporting logics and social norms that are common in the broader society, as well as legitimizing them within the organization. According to Bapuji et al. [12], the acceptance of inequality as normal in a society reduces the inducements and investments employers offer their employees and result in unethical employee attitudes, which modifies the nature of the employment relationship. In short, income inequality decreases organizational equilibrium. Therefore, we propose that:

Hypothesis 1. There is a negative bidirectional relationship between income inequality and organizational equilibrium.

\section{Methodology}

\subsection{Sources of Information and Measures}

This empirical study was conducted in Spain because it is one of the Organization for Economic Co-operation and Development (OECD) member countries in which income inequality has most increased following the 2008 economic crisis, as well as where income inequality distribution among regions is most disparate $[49,50]$. Spain is fifth in the list of the 28 OECD countries according to the difference between maximum and minimum Gini coefficient values for regional household disposable income [50]. In addition, as can be seen in Figure 1, there is no pattern of common evolution between Spanish regions. Similar to Cobb and Stevens [8] and Roca-Puig [11], we exploit this regional variation in income inequality to examine the society-organization link, and measure income inequality through the Gini coefficient, which measures the extent to which income from households deviates from a perfectly equal distribution. The Gini coefficient takes the value of 0 in the case of perfect equity and 100 in the case of perfect inequality. We used the Gini coefficient calculated and published by the 
Spanish Statistical Office (Instituto Nacional de Estadística, INE) from the Living Conditions Survey 2008-2016 for each of the 17 Spanish regions, corresponding to Nomenclature of Territorial Units for Statistics or NUTS 2 level regions in Europe. The Living Conditions Survey is an annual statistical survey of households that is carried out in all European Union member states. This survey asks about incomes in the previous year, so the reported Gini coefficients are actually for 2007 through 2015.

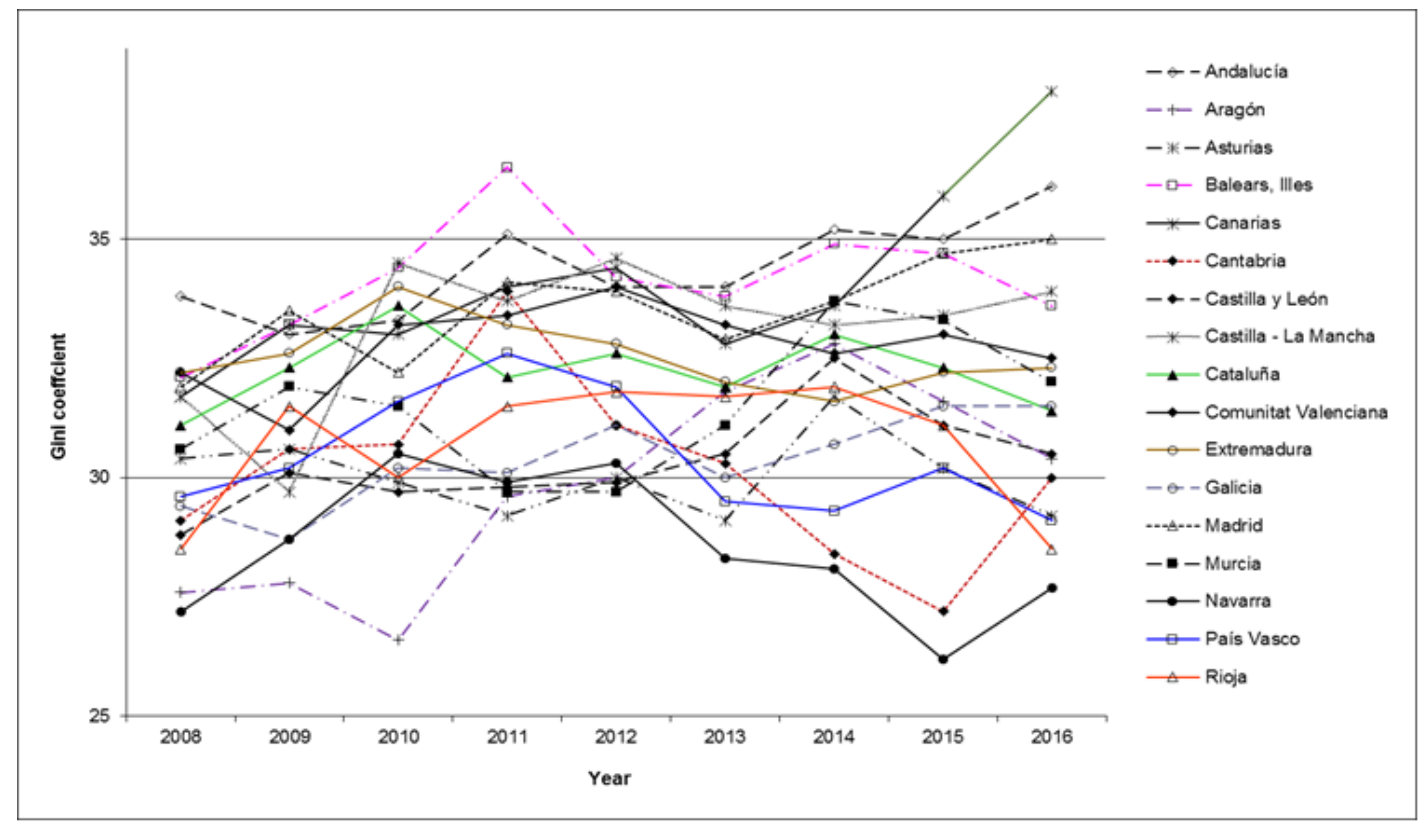

Figure 1. Progress of income inequality by Spanish regions. Source: Spanish Statistical Office.

We also collected data for the 2007-2015 period from the Business Strategy Survey (Encuesta sobre Estrategias Empresariales, ESEE), published by the Sociedad Estatal de Participaciones Industriales (SEPI) Foundation ([51]) to measure organizational variables. The data companies provide for the ESEE correspond exactly to the published year. All the variables included in this panel database are annual, and the reference population is Spanish industrial firms with ten or more employees. Irregular cases that might skew the data were removed from the original ESEE sample for the period 2007-2015 (3108 firms). These cases included, first, firms affected by takeovers, divisions or mergers (322 firms), all of which prevent data being compared over time. A concentration of these firms in a particular region is not appreciated. Then we eliminated firms with industrial premises located in more than one region (249 firms), and those that moved from one region to another during the period studied (12 firms), since these cases cannot be assigned a single Gini coefficient. The final sample for analysis contained 2525 firms that report information in at least one year in the nine-year study period. Their distribution by region is shown in Table 1. Information for some years is missing, mainly due to firms that enter or exit the panel over time. Missing values in panel data are more often the norm than the exception ([39]).

To measure organizational variables, we rely on the recent studies by Roca-Puig et al. [31] and Roca-Puig [11]. We calculated the HR investment variable as the arithmetic mean of the standardized values of the employees' average salary, investment in training, and job security. The average salary was calculated as the ratio of labor costs to total number of employees. Investment in training was calculated as the ratio of training expenditure to total number of employees in the firm. Finally, job security was calculated as the percentage of all the firm's employees with a permanent contract. The labor productivity variable was measured with the ratio of value added to the number of employees in the firm, and a logarithmic transformation of this ratio was performed. Value added assessed employees' labor efficiency by considering economic output in relation to operating costs. Drawing on Venkatraman [52] and Roca-Puig [21], the use of SEM allows us to operationalize organizational 
equilibrium as a latent variable that denotes the positive coalignment between labor productivity and HR investment. In addition, Roca-Puig et al. [31] have identified organizational size and capital intensity as variables that can affect both HR investment and labor productivity and, therefore, could affect the organization's coalignment (i.e., organizational equilibrium). We, therefore, applied these two organizational characteristics as control variables. Organizational size was measured as the logarithm of the total number of employees in the firm, and capital intensity was calculated as the logarithm of the ratio of net fixed assets to total number of employees.

Table 1. Distribution of the number of firms by Spanish regions.

\begin{tabular}{|c|c|c|}
\hline Andalucía & 265 & $10.5 \%$ \\
\hline Aragón & 96 & $3.8 \%$ \\
\hline Asturias & 56 & $2.2 \%$ \\
\hline Balears, Illes & 31 & $1.2 \%$ \\
\hline Canarias & 39 & $1.5 \%$ \\
\hline Cantabria & 29 & $1.1 \%$ \\
\hline Castilla y León & 134 & $5.3 \%$ \\
\hline Castilla-La Mancha & 134 & $5.3 \%$ \\
\hline Cataluña & 498 & $19.7 \%$ \\
\hline Comunitat Valenciana & 381 & $15.1 \%$ \\
\hline Extremadura & 37 & $1.5 \%$ \\
\hline Galicia & 159 & $6.3 \%$ \\
\hline Madrid & 286 & $11.3 \%$ \\
\hline Murcia & 78 & $3.1 \%$ \\
\hline Navarra & 72 & $2.9 \%$ \\
\hline País Vasco & 191 & $7.6 \%$ \\
\hline Rioja & 39 & $1.5 \%$ \\
\hline Total & 2525 & $100 \%$ \\
\hline
\end{tabular}

\subsection{Statistical Procedure}

Following Little [39] and Roca-Puig [11], a cross-lagged longitudinal SEM was designed to examine the bilateral relationship between organizational equilibrium and income inequality during the nine-year study period $(t=9)$. As mentioned above, the organizational equilibrium variable is constructed by means of a common latent factor that collects the covariation between labor productivity and HR investment variables in the same year. In SEM nomenclature, as seen in Figure 2, a common latent factor is graphically represented by a circle [53]. The organizational equilibrium variable scale was set by fixing the path from the factor to labor productivity to 1 . The magnitudes of cross-lagged effects and the path from the organizational equilibrium to HR investment were constrained to be equal over time to ensure greater parsimony of the model and to facilitate the interpretation of the results [54]. In addition, because the sample included firms with missing data, we used full information maximum likelihood (FIML) to estimate the model parameters. The FIML approach is preferred to the classic listwise deletion because it produces more consistent estimates [39,54]. In addition, robust standard errors were used to protect inferences from non-normality of the data. When missing values are accompanied by non-normality, the robust FIML method yields the best parameter estimates [55]. To assess the fit of the model to the data, we used EQS software [53]; we report the Yuan-Bentler scaled chi-square statistic $(\chi 2)$, the Bentler-Bonett non-normed fit index (BBNFI), the comparative fit index 
(CFI), the root mean square error of approximation (RMSEA), and the standardized root mean square residual (SRMR).

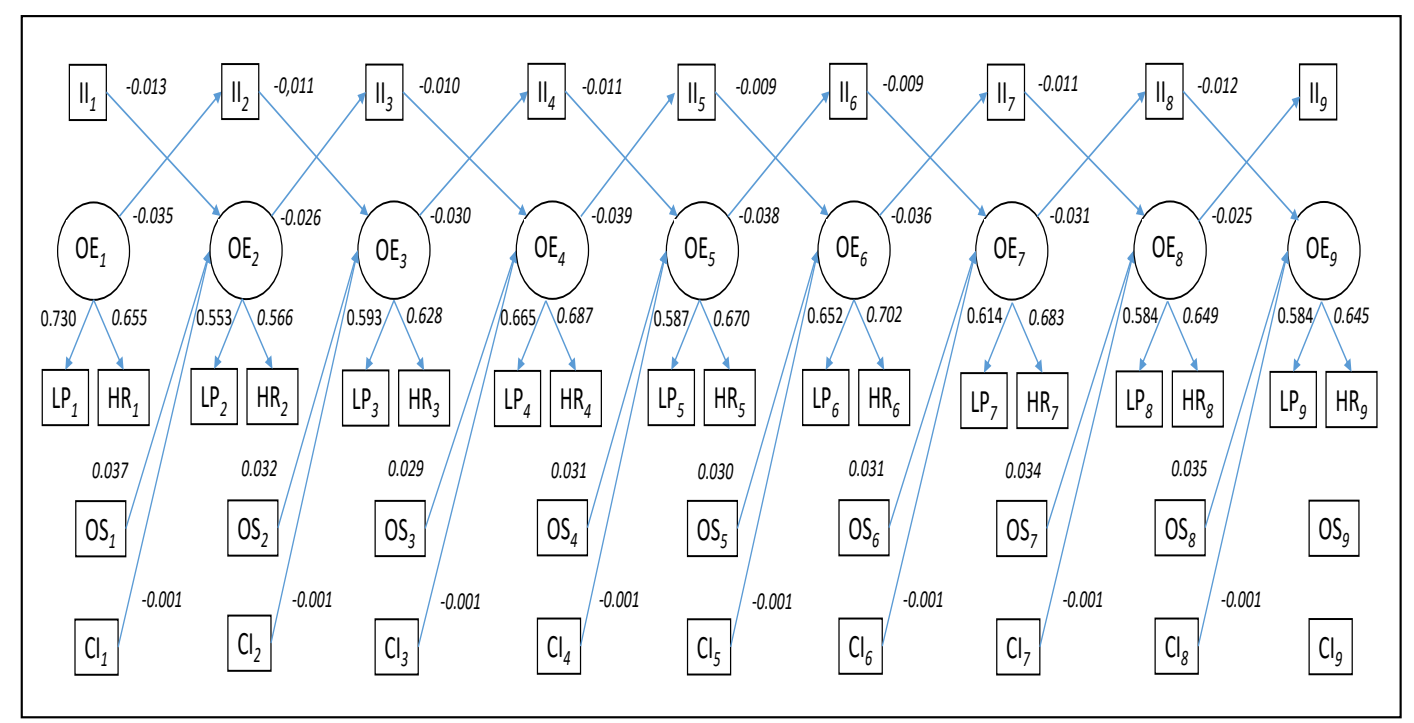

Figure 2. Results of longitudinal model (standardized solution). Note: 1. II: Income inequality; $O E$ : Organizational equilibrium; LP: Labor productivity; HR: Human resource investment; OS: Organizational size; CI: Capital intensity. The subscripts indicate the different moments of time $(t=9$ years). 2. For the sake of simplicity, the estimated parameters of autoregressive effects are omitted in this graphical representation.

\section{Results}

We obtained acceptable values in accordance with the usual criteria applied to evaluate the goodness of fit of a model to the data (scaled $\chi 2=7960.21$, d.f. 818; BBNFI =0.903; CFI =0.909; RMSEA $=0.059 ; \mathrm{SRMR}=0.079$ ). The unstandardized parameter estimates are presented in Table 2 and the robust test statistic was used to evaluate their level of significance. First, note that a positive pattern of common variation emerges between HR investment and labor productivity (2434; Organizational

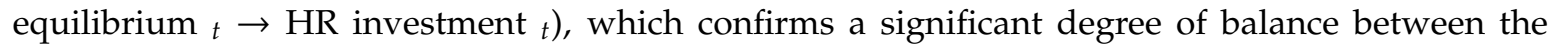
interests of employers and those of employees. This organizational equilibrium is configured from a social exchange relationship between these two internal stakeholders developed over time. Second, the bidirectional hypothesis posed in this research is corroborated because income inequality negatively affects organizational equilibrium (-0.001; Income inequality $t \rightarrow$ Organizational equilibrium $t+1)$, and vice versa: organizational equilibrium also negatively affects a society's income inequality $(-0.309$; Organizational equilibrium $t \rightarrow$ Income inequality $t+1$ ). In other words, a positive bidirectional relationship is shown between income equality and organizational equilibrium. Moreover, as seen in Figure 2, the double causality between organizational equilibrium and income inequality draws a helical chain configured over time, simultaneously strengthening organizational social sustainability and societal social sustainability. A reduction in income inequality at a moment in time $(t)$ will produce an increase in the organizational equilibrium in the future $(t+1)$, which in turn will subsequently $(t+2)$ cause a decline in income inequality. An analogous feedback loop will occur if the organizational equilibrium is improved at a moment of time $(t)$. A bidirectional relationship emerges in which income inequality and organizational equilibrium are, in turn, cause and effect at different times. 
Table 2. Results of longitudinal model (unstandardized solution).

\begin{tabular}{|c|c|}
\hline Causal Relationships & Parameter Estimates \\
\hline Organizational equilibrium $t \rightarrow$ Labor productivity $t$ & 1 \\
\hline Organizational equilibrium $t_{t} \rightarrow \mathrm{HR}$ investment $t_{t}$ & $2.434 * * *$ \\
\hline Organizational equilibrium $t_{t} \rightarrow$ Income inequality $t+1$ & $-0.309^{* * *}$ \\
\hline $\begin{aligned} \text { Income inequality } t & \rightarrow \text { Organizational equilibrium } t+1 \\
& \text { Control effects }\end{aligned}$ & $-0.001 * *$ \\
\hline Organizational size $t_{t} \rightarrow$ Organizational equilibrium $_{t+1}$ & $0.011^{* * *}$ \\
\hline $\begin{array}{c}\text { Capital intensity } t \rightarrow \text { Organizational equilibrium } t+1 \\
\text { Autoregressive effects }\end{array}$ & -0.000 \\
\hline Income inequality $t \rightarrow$ Income inequality $t+1$ & $(0.685-1.097)^{* * *}$ \\
\hline Organizational equilibrium $t \rightarrow$ Organizational equilibrium $t+1$ & $(0.762-1.119)^{* * *}$ \\
\hline Organizational size $t_{t} \rightarrow$ Organizational size $t+1$ & $(0.997-1.015) * * *$ \\
\hline Capital intensity $t \rightarrow$ Capital intensity $t+1$ & $(0.928-0.975)^{* * *}$ \\
\hline
\end{tabular}

Note: Autoregression coefficients are not equal over time; the range of variation (minimum-maximum) reached during the analyzed period is therefore shown in parenthesis. $N=2525 .{ }^{* *} p<0.05 ;{ }^{* *} p<0.01$.

\section{Discussion and Conclusion}

Studies that provide empirical evidence on the role organizations play in configuring a dynamic of income equality regeneration are fundamental to cement and develop the society-business binomial $[8,9,34]$. In this study, we focused on the bilateral relationship between income equality and organizational equilibrium. We proposed that each one needs the other, each one influences the other, thus configuring a symbiotic relationship beneficial to both parties--society and business--that reinforces their sustainability over time $[27,28,36,41]$. We applied stakeholder theory and institutional theory, two of the most frequently used management theories in the corporate sustainability literature [16,33], to develop this bidirectional hypothesis. Our findings corroborate the benefits to society of the organizational equilibrium achieved by companies and, in turn, the benefits to companies of the income equality that a society enjoys. Hence, the greater the distributive equity of the employment relationship in organizations, the greater the equity in the distribution of income of people in a society, and vice versa. This interactive cycle proves that society and companies complement and enhance each other over time, identifying a causal feedback loop between societal social sustainability and organizational social sustainability whereby the "cause" might also be affected by the "effect" [11,34]. According to Porter and Kramer [28], the final product is the creation of a virtuous circle of shared value in which an improvement in the degree of sustainability in one of these social collectivities leads to an improvement in the other.

\subsection{Theoretical and Practical Implications}

Our research makes some important contributions in the field of management by exploring the connection between companies' actions and the problems facing society, among which income inequality stands out (e.g., $[8,9,12,13,15])$. Income inequality and its causes and consequences have become one of the most important topics of reflection and analysis of our time [12]. We can differentiate between studies arguing that income inequality causes organizational practices (e.g., [2]), from others claiming that organizational practices cause income inequality (e.g., [3]). Both points of view-which a priori can be perceived as antagonistic, given the causal dilemma that emerges-actually become compatible if we embrace the bidirectional relationship between them. Bapuji et al. [12] have recently highlighted this scenario and expose a more comprehensive framework for the society-business link. Our research provides empirical evidence of this bidirectional relationship, by showing that organizational equilibrium is both a cause and a consequence of income inequality. How companies reward employees for their labor productivity is an important determinant of how income is distributed in a society, and vice versa. Likewise, the existence of this two-way relationship confirms that stakeholder and institutional theoretical approaches from the corporate sustainability literature are 
concurrent [16], and, in addition, it is consistent with the circular vision of the social sustainability revealed by recent studies (e.g., [11,45]).

Additionally, Bapuji et al. [12,13] recommend extending current management theories to examine the creation of income inequality due to actions and strategies of organizations. Similarly, there have been repeated calls in the sustainability literature to extend inquiry to relevant fields of management research (e.g., [56]). These two research fields need to work more closely with each other. In this line, we exposed the concept of organizational equilibrium [19] and explicitly incorporated it into the field of corporate sustainability. March and Simon [19] have had a significant influence on academic scholarship, and a growing number of scholars are returning to their core concepts for inspiration to facilitate and enhance their own work across a variety of fields [57]. Moreover, the corporate sustainability approach usually advocates organizational equilibrium theoretically and implicitly. The challenge is to operationalize and integrate conceptual notions of "balance" or "equilibrium" referred to in the sustainability literature [5]. Responding to this call, we have carried out a new operationalization of the concept based on the positive covariation pattern between the incentives that employees receive from the organization (i.e., HR investment) and the contributions they make to the organization (i.e., labor productivity). Using SEM, this common variation is expressed by means of a latent factor [52]; covariance between HR investment and labor productivity is a simple indicator, generalizable to any type of company, which could easily be incorporated into its sustainability reports. Furthermore, as Eizenberg and Jabareen [47], Muñoz-Martín [41] and Di Vaio et al. [58] claim, the selection of indicators of organizational social sustainability is not often based on theory, but on passing trends, which has generated a certain skepticism in the field of corporate sustainability. In this regard, it is important to stress that the choice of this indicator rests on March and Simon's [19] well-established inducement-contribution model.

Schaltegger et al. [17] state that the traditional position in corporate sustainability research focused mainly on identifying different ideal types of sustainability-oriented business models (e.g., $[18,26])$. We note these business models as organizational configurations. Configurations represent common alignments of elements, and a typology defines them by means of a theoretical or qualitative description of many consistent elements [59]. Alternatively, configuration can be seen as a quality, defined by the degree of coalignment or consistency between different elements [59]. Our study retains this last definition by focusing on the pattern of relationships between HR investment and labor productivity that make up a sustainable organizational configuration. In the sustainability literature, the central orchestrating theme that justifies a close alignment of these two elements is the balance between the interests of employers and those of employees. Our findings corroborate this normative principle of sustainability since a win-win pattern emerges between these two internal stakeholders. The two configurational approaches complement each other, thus enriching the field of corporate sustainability.

The symbiotic relationship between organizational equilibrium and income equality is grounded in the ethical principle of equity, normally supported in the sustainability research (e.g., [5,18,29,41,47]). Society and organizations act as communicating vessels between which equity flows. This ethical value is enhanced (or degraded) in each of these two domains and is transferred between them. Our findings reveal that this flow works in both directions, since equity represents a bridge between societal social sustainability and organizational social sustainability. The boundaries typically created between these different fields of study make it difficult to obtain a complete picture of sustainability [26]. The spread of cultural values, such as equity, is required to facilitate a joint sustainable development of society and business.

\subsection{Limitations and Future Research}

Dyllick and Hockerts [35] and Cosenz et al. [34] identify three areas of sustainability, namely economic (business), social (society), and ecological (nature), which are interrelated, and may, therefore, influence each other in multiple ways. Our study focuses on the relationship between business and society, without exploring the third dimension. Future research could include the area of 
ecological sustainability to form a more complete sustainability framework analysis. For example, the UN's 2030 Agenda for Sustainable Development and authors, such as Uzar and Eyuboglu [60], Agyeman et al., [61], and Eizenberg and Jabareen [47], claim that it is difficult to improve natural environmental aspects without simultaneously advancing on more social environmental issues, such as reducing income inequality. Geographical areas with a more equitable income distribution tend to have a higher environmental quality (e.g., less pollution). In this way, we could examine the mediating role of income inequality in the relationship between organizational equilibrium and environmental pollution. In addition, future research could apply longitudinal SEM to examine whether results vary for different types of companies. For example, given that small firms can play a crucial role in contributing to improve societal social sustainability [48], it would be interesting to conduct a comparative analysis between small and large firms. On the other hand, the business-society interface is not a simple boundary, but rather a space of dispute where different parties formally promote their interests through different legal regulations [62]. In this context, modifications in the legal framework in which the business-society binomial operates over time may affect the obligations of companies and society to distribute resources more fairly; future research could, therefore, examine how changes in legal policies may affect income inequality and organizational equilibrium, as well as the two-way relationship between them.

Unfortunately, the serious COVID-19 pandemic currently affecting all countries will probably alter the ethical value of equity or distributive justice, both in organizations and in society $[13,21,63]$. Future research could usefully replicate our study and, adopting a comparative approach, analyze whether significant differences arise in the relationships proposed in our model between pre- and post-2020 periods. This year will probably mark a turning point that substantially modifies the study of the interplay between organizations and societies. As Bapuji et al. [13] point out, this current crisis accentuates the need for management scholars to take a societal turn and analyze how organizational practices interact with income inequality.

In conclusion, the bidirectional connection between organizational actions and the living conditions of the population is an essential topic in the corporate sustainability literature. Our study presents a novel proposal to verify the two-way causal relation between organizational equilibrium and income inequality over time. As such, it should be considered as an initial step to future research exploring the symbiotic process between business and society. Our findings encourage companies to improve their organizational equilibrium, thus contributing to an equitable and sustainable development of both society and business. Sustainable companies need a sustainable society and, simultaneously, a sustainable society needs sustainable companies.

Funding: This research was funded by the Spanish Ministry of Science and Innovation (Ref. ECO2015-66671-P MINECO/FEDER), by the Universitat Jaume I (Ref. UJI-B2017-21), and by the Generalitat Valenciana (Ref. AICO/2019/184).

Conflicts of Interest: The author declare no conflict of interest.

\section{References}

1. Wilkinson, R.G.; Pickett, K.E. The Spirit Level. Why More Equal Societies Almost Always do Better; Allen Lane: London, UK, 2009.

2. Bapuji, H. Individuals, interactions and institutions: How economic inequality affects organizations. Hum. Relat. 2015, 68, 1059-1083. [CrossRef]

3. Cobb, J.A. How Firms Shape Income Inequality: Stakeholder Power, Executive Decision Making, and the Structuring of Employment Relationships. Acad. Manag. Rev. 2016, 41, 324-348. [CrossRef]

4. Bansal, P. Evolving sustainably: A longitudinal study of corporate sustainable development. Strat. Manag. J. 2005, 26, 197-218. [CrossRef]

5. Boström, M. A missing pillar? Challenges in theorizing and practicing social sustainability: Introduction to the special issue. Sustain. Sci. Pr. Policy 2012, 8, 3-14. [CrossRef] 
6. Hutchins, M.J.; Sutherland, J.W. An exploration of measures of social sustainability and their application to supply chain decisions. J. Clean. Prod. 2008, 16, 1688-1698. [CrossRef]

7. Sharma, S.; Ruud, A. On the path to sustainability: Integrating social dimensions into the research and practice of environmental management. Bus. Strat. Environ. 2003, 12, 205-214. [CrossRef]

8. Cobb, J.A.; Stevens, F.G. These Unequal States: Corporate Organization and Income Inequality in the United States. Adm. Sci. Q. 2016, 62, 304-340. [CrossRef]

9. Tsui, A.S.; Enderle, G.; Jiang, K. Income Inequality in the United States: Reflections on the Role of Corporations. Acad. Manag. Rev. 2018, 43, 156-168. [CrossRef]

10. Bidwell, M.; Briscoe, F.; Fernandez-Mateo, I.; Sterling, A. The Employment Relationship and Inequality: How and Why Changes in Employment Practices are Reshaping Rewards in Organizations. Acad. Manag. Ann. 2013, 7, 61-121. [CrossRef]

11. Roca-Puig, V. The circular path of social sustainability: An empirical analysis. J. Clean. Prod. 2019, 212, 916-924. [CrossRef]

12. Bapuji, H.; Ertug, G.; Shaw, J.D. Organizations and Societal Economic Inequality: A Review and Way Forward. Acad. Manag. Ann. 2020, 14, 60-91. [CrossRef]

13. Bapuji, H.; Patel, C.; Ertug, G.; Allen, D.G. Corona Crisis and Inequality: Why Management Research Needs a Societal Turn. J. Manag. 2020, 46, 1205-1222. [CrossRef]

14. Chams, N.; García-Blandón, J. On the importance of sustainable human resource management for the adoption of sustainable development goals. Resour. Conserv. Recycl. 2019, 141, 109-122. [CrossRef]

15. Marens, R. Laying the Foundation: Preparing the Field of Business and Society for Investigating the Relationship Between Business and Inequality. Bus. Soc. 2016, 57, 1252-1285. [CrossRef]

16. Barrena-Martínez, J.; López-Fernández, M.; Romero-Fernández, P.M. Corporate social responsibility: Evolution through institutional and stakeholder perspectives. Eur. J. Manag. Bus. Econ. 2016, 25, 8-14. [CrossRef]

17. Schaltegger, S.; Hansen, E.G.; Lüdeke-Freund, F. Business models for sustainability: Origins, present research, and future avenues. Organ. Environ. 2015, 29, 3-10. [CrossRef]

18. Stubbs, W.; Cocklin, C. Conceptualizing a "Sustainability Business Model". Organ. Environ. 2008, 21, 103-127. [CrossRef]

19. March, J.G.; Simon, H.A. Organizations; Wiley: New York, NY, USA, 1958.

20. Tsui, A.S.; Pearce, J.L.; Porter, L.W.; Tripoli, A.M. Alternative Approaches to the Employee-Organization Relationship: Does Investment in Employees Pay Off? Acad. Manag. J. 1997, 40, 1089-1121. [CrossRef]

21. Roca-Puig, V. The Dual Role of Human Resource Investment in Social Inequality. Revista de Trabajo y Seguridad Social. 2020. Available online: https://www.laboral-social.com/doble-rol-de-inversion-recursos-humanosdesigualdad-social.html (accessed on 7 October 2020).

22. Freeman, R.E.; Harrison, J.S.; Wicks, A.C.; Parmar, B.L.; De Colle, S. Stakeholder Theory: The State of the Art; Cambridge University Press: Cambridge, UK, 2010.

23. Perrini, F.; Tencati, A. Sustainability and stakeholder management: The need for new corporate performance evaluation and reporting systems. Bus. Strat. Environ. 2006, 15, 296-308. [CrossRef]

24. Plaza-Úbeda, J.A.; Burgos-Jiménez, J.; Vazquez, D.A.; Liston-Heyes, C. The 'win-win'paradigm and stakeholder integration. Bus. Strat. Environ. 2009, 18, 487-499. [CrossRef]

25. Stankevičiūtè, Ž.; Savanevičienè, A. Designing sustainable HRM: The core characteristics of emerging field. Sustainability 2018, 10, 4798. [CrossRef]

26. Bocken, N.; Short, S.; Rana, P.; Evans, S. A literature and practice review to develop sustainable business model archetypes. J. Clean. Prod. 2014, 65, 42-56. [CrossRef]

27. Porter, M.E.; Kramer, M.R. Strategy and society: The link between competitive advantage and corporate social responsibility. Harv. Bus. Rev. 2006, 84, 77-92.

28. Porter, M.E.; Kramer, M.R. Creating shared value. Harv. Bus. Rev. 2011, 1-2, 1-17.

29. Santos, M.J. Theoretical contributions towards rethinking corporate social responsibility. Manag. Res. J. Iberoam. Acad. Manag. 2014, 12, 288-307. [CrossRef]

30. Amis, J.M.; Munir, K.A.; Lawrence, T.B.; Hirsch, P.; McGahan, A. Inequality, Institutions and Organizations. Organ. Stud. 2018, 39, 1131-1152. [CrossRef]

31. Roca-Puig, V.; Beltrán-Martín, I.; García-Juan, B. Incorporating poverty in society into strategic human resource management. Int. J. Hum. Resour. Manag. 2019, 1-24. [CrossRef] 
32. Powell, W.W.; DiMaggio, P.J. The New Institutionalism in Organizational Analysis; University of Chicago Press: Chicago, IL, USA, 2012.

33. Todaro, N.M.; Daddi, T.; Testa, F.; Iraldo, F. Organization and management theories in environmental management systems research: A systematic literature review. Bus. Strat. Dev. 2019, 3, 39-54. [CrossRef]

34. Cosenz, F.; Rodrigues, V.P.; Rosati, F. Dynamic business modeling for sustainability: Exploring a system dynamics perspective to develop sustainable business models. Bus. Strat. Environ. 2020, 29, 651-664. [CrossRef]

35. Dyllick, T.; Hockerts, K. Beyond the business case for corporate sustainability. Bus. Strat. Environ. 2002, 11, 130-141. [CrossRef]

36. Gonçalves das Neves, J.; Simões, E.; Duarte, A.P. Introduction to the special issue on ethics, social responsibility and sustainability. Manag. Res. J. Iberoam. Acad. Manag. 2014, 12, 219-221. [CrossRef]

37. Jerónimo-Silvestre, W.; Antunes, P.; Filho, W.L. The corporate sustainability typology: Analysing sustainability drivers and fostering sustainability at enterprises. Technol. Econ. Dev. Econ. 2016, 24, 513-533. [CrossRef]

38. Saridakis, G.; Lai, Y.; Cooper, C.L. Exploring the relationship between HRM and firm performance: A meta-analysis of longitudinal studies. Hum. Resour. Manag. Rev. 2017, 27, 87-96. [CrossRef]

39. Little, T.D. Longitudinal Structural Equation Modeling; Guilford Press: New York, NY, USA, 2013.

40. Garriga, E.; Melé, D. Corporate Social Responsibility Theories: Mapping the Territory. J. Bus. Ethics 2004, 53, 51-71. [CrossRef]

41. Muñoz-Martín, J. Business ethics, corporate social responsibility (CSR) and creation of shared value (CVC). J. Glob. Compet. Gov. 2013, 7, 76-88. [CrossRef]

42. Rodríguez-Fernández, J.M.R. Modelo stakeholder y responsabilidad social: El gobierno corporativo global. M@n@gement 2008, 11, 81. [CrossRef]

43. Boxall, P. Mutuality in the management of human resources: Assessing the quality of alignment in employment relationships. Hum. Resour. Manag. J. 2013, 23, 3-17. [CrossRef]

44. Clipa, A.-M.; Clipa, C.-I.; Danileț, M.; Andrei, A.G. Enhancing Sustainable Employment Relationships: An Empirical Investigation of the Influence of Trust in Employer and Subjective Value in Employment Contract Negotiations. Sustainability 2019, 11, 4995. [CrossRef]

45. Padilla-Rivera, A.; Russo-Garrido, S.; Merveille, N. Addressing the Social Aspects of a Circular Economy: A Systematic Literature Review. Sustainability 2020, 12, 7912. [CrossRef]

46. Subramony, M.; Krause, N.; Norton, J.; Burns, G.N. The relationship between human resource investments and organizational performance: A firm-level examination of equilibrium theory. J. Appl. Psychol. 2008, 93, 778-788. [CrossRef]

47. Eizenberg, E.; Jabareen, Y. Social Sustainability: A New Conceptual Framework. Sustainability 2017, 9, 68. [CrossRef]

48. Westman, L.; Luederitz, C.; Kundurpi, A.; Mercado, A.J.; Weber, O.; Burch, S.L. Conceptualizing businesses as social actors: A framework for understanding sustainability actions in small- and medium-sized enterprises. Bus. Strat. Environ. 2018, 28, 388-402. [CrossRef]

49. Piacentini, M. Measuring income inequality and poverty at the regional level in OECD countries. Stat. Work. Pap. 2014, 2014/03, 1-62.

50. OECD. How's Life in Four Region? Insights from Income Distribution and Poverty in OECD Regions. 2014. Available online: http://www.oecd.org/regional/how-is-life-in-your-region.htm (accessed on 8 March 2020).

51. SEPI Foundation. Survey on Business Strategy (ESEE). 2019. Available online: https://www.fundacionsepi. es/investigacion/esee/en/spresentacion.asp (accessed on 6 September 2019).

52. Venkatraman, N. Performance implications of strategic coalignment: A methodological perspective. J. Manag. Stud. 1990, 27, 19-41. [CrossRef]

53. Bentler, P.M. EQS 6 Structural Equation Program Manual; Multivariate software, Inc.: Encino, CA, USA, 2006; Available online: http://www.econ.upf.edu/ \{\}satorra/CourseSEMVienna2010/EQSManual.pdf (accessed on 15 July 2020).

54. Cole, D.A.; Maxwell, S.E. Testing Mediational Models With Longitudinal Data: Questions and Tips in the Use of Structural Equation Modeling. J. Abnorm. Psychol. 2003, 112, 558-577. [CrossRef] [PubMed]

55. Shin, T.; Davison, M.L.; Long, J.D. Effects of Missing Data Methods in Structural Equation Modeling With Nonnormal Longitudinal Data. Struct. Equ. Model. A Multidiscip. J. 2009, 16, 70-98. [CrossRef] 
56. Wolff, R. Beyond environmental management-perspectives on environmental and management research. Bus. Strategy Environ. 1998, 7, 297-308. [CrossRef]

57. Wilden, R.; Hohberger, J.; DeVinney, T.M.; Lumineau, F. 60 Years of March and Simon's Organizations: An Empirical Examination of its Impact and Influence on Subsequent Research. J. Manag. Stud. 2019, 56, 1570-1604. [CrossRef]

58. Di Vaio, A.; Palladino, R.; Hassan, R.; Alvino, F. Human resources disclosure in the EU Directive 2014/95/EU perspective: A systematic literature review. J. Clean. Prod. 2020, 257, 120509. [CrossRef]

59. Miller, D. Configurations revisited. Strateg. Manag. J. 1996, 17, 505-512. [CrossRef]

60. Uzar, U.; Eyuboglu, K. The nexus between income inequality and $\mathrm{CO}_{2}$ emissions in Turkey. J. Clean. Prod. 2019, 227, 149-157. [CrossRef]

61. Agyeman, J.; Bullard, R.D.; Evans, B. Exploring the Nexus: Bringing Together Sustainability, Environmental Justice and Equity. Space Polity 2002, 6, 77-90. [CrossRef]

62. Sheehy, B. Defining CSR: Problems and Solutions. J. Bus. Ethics 2014, 131, 625-648. [CrossRef]

63. Cooke, F.L.; Dickmann, M.; Parry, E. IJHRM after 30 years: Taking stock in times of COVID-19 and looking towards the future of HR research. Int. J. Hum. Resour. Manag. 2020. [CrossRef]

Publisher's Note: MDPI stays neutral with regard to jurisdictional claims in published maps and institutional affiliations.

(C) 2020 by the author. Licensee MDPI, Basel, Switzerland. This article is an open access article distributed under the terms and conditions of the Creative Commons Attribution (CC BY) license (http://creativecommons.org/licenses/by/4.0/). 